\title{
Determinants of Capital Adequacy of Commercial Banks in Ethiopia
}

\author{
Ifa Akuma(Msc) \\ Lecturer, Department of Accounting and Finance, College of Business and Economics, Wollega University, \\ Nekemte, Ethiopia
}

\begin{abstract}
This thesis aimed to see the determinant factors for capital adequacy using seven (7) selected banks operating in Ethiopia from 2007 to 2019. The research conducted different estimation to see the relationship between the dependent variable, Capital Adequacy Ratio (CAR) and independent Variables which include Bank size (SIZE), DAR (Deposit to Asset Ratio), Loan to Asset Ratio (LAR), Loan to Deposit (LTD), Return on Asset (ROA), Return on Equity (ROE), Loan Loss Provision (LPR), and macroeconomic variables (gross domestic product and inflation). The variables SIZE, DAR, LAR and ROE affect CAR negatively whereas ROA and LPR affects positively. Hence, it is recommended that to be sure that banks have adequate adequacy reserve, commercial banks and National Bank of Ethiopia should give attention to the risk associated with banks size, caring of banks loan and deposit, initiating to increase their return on their asset and to manage their equity return.
\end{abstract}

Keywords: capital, adequacy and commercial banks, Ethiopia.

DOI: $10.7176 /$ RJFA/11-21-05

Publication date: November $30^{\text {th }} 2020$

\section{Introduction}

Capital adequacy as a concept has been in existence prior to the era of capital regulation in the banking industry and there exist several literatures on the determination of capital adequacy ratio (CAR) as well as its determinants. The concept appeared in the middle of the 1970's because of the expansion of lending activities in banks without any parallel increase in its capital, since capital ratio was measured by total capital divided by total assets (AlSabbagh, 2004). This led to the evolution of international debt crisis and the failure of one of the biggest American banks, Franklin National Bank (Koehn and Santomero, 1980).These events forced regulatory authorities to stress more control procedures and to improve new criteria and methods to avoid bank's insolvency (Al-Sabbagh, 2004).

The Basel Committee on Banking supervision (BCBS) have authority to strengthen regulation and improve the quality of banking supervision worldwide (Bank for International Settlement). The committee publish Basle Capital Accord, it decide to define minimum capital adequacy ratio in the amount of $8 \%$ of risk weighted assets is standardize international banks (Nuviyanti and Anggono, 2014).Using minimum capital adequacy ratios causes promotion instability and inefficiency of the financial system by decreasing the likelihood of insolvency in banks. In the aftermath of the 2007 financial crisis, there have been efforts by regulatory authorities to make banks stronger. To accomplish this, governments across the developed world are enforcing to strengthen their balance sheets by increasing capital, and if they cannot raise more capital, they are told to decrease the amount of risk assets (loans) on their books (Abba, 2013).

The National Bank of Ethiopia (NBE), as a central bank, control over the banking sector through issuance of directives pertaining formation and operation of a banking business. NBE has articulated in its Banks Directives No. SBB/50/2011 sub article 4 mentioned that all licensed banks shall at a minimum maintain capital to risk weighted assets ratio of $8 \%$ at all times. Thus, given the unique features of banking sector and environment in which they operate and also rapid expansion of banking institutions in Ethiopia, this study seeks to providing full information about the bank specific and macroeconomic determinants of CAR of commercial banks in Ethiopia by examining the untouched one, and replicating the existing in the Ethiopian context by using all commercial banks operating in the country before 2007. This research excluding infant banks as estimation infant banks cannot give more relevant information because of recently established.

\section{Statement of the Problem}

Capital adequacy ratio (CAR) is an important risk-based measurement. The aim of the regulatory capital adequacy ratio is to prevent a bank's bankruptcy and the negative externality of a financial crisis. Besides this, the relationship between the capital adequacy ratio and macroeconomic and banking factors is very important taking into account that the bank capital serves as cushion in case the value of the bank's assets declines or its liabilities rise. There are a lot of academics and other financial institutions that have tried to investigate the main factors that determine the capital adequacy ratio. For instance, Williams (2011) studied the impact of macroeconomic variables on the CAR; he noted that macroeconomic variables such as inflation, real exchange rate, money supply, political instability, and Return on investment are significant determinants of regulatory capital., while Hortlund (2005) tested the impact of inflation on the capitalization of Swedish banks and demonstrated that inflation and the banks 
regulatory capital ratios were inversely related. Yuanjua and Shishun (2012) analyze the relationship between the capital adequacy ratio (CAR) and some internal banking variables they found a positive relationship between ROA and CAR but a negative relationship between C A R a n d ROE whereas (Bateni 2014) found positive relationship between Return on Equity (ROE) and capital adequacy ratio, in contrary to those results Shingjergji and Hyseni (2015) also found out that profitability indicators such as ROA and ROE do not have any influence on CAR in the Albanian banking system. Furthermore, Buyuksalvarci and Abdioglu (2011) concluded that leverage have a negative effect on capital adequacy ratio while Ahmed et al. (2009) concluded that leverage do have a positive impact on bank capital. Al-Sabbagh (2004) stated in his study deposits positively affected to CAR while Bokhari and Ali (2009) share of deposits is strongly negatively affected to CAR. However, the results of those studies were inconsistent. This inconsistency of results might be attributable to the method of data analysis used by different researchers and difference in the economic condition of the countries in which banking sectors are operating.

Besides, there are inconsistent results in literature regarding the effect of some variables on CAR, for example, Yonas (2015), Ali et al. (2006) and Khanal et al. (2003) found a negative relationship between ROE and CAR while Khrawish (2011) and Molyneux and Thornton (1992) found a positive relationship between ROE and CAR.In light of the above facts and the research gaps, the aim of this study is to examine bank specific and macroeconomic determinants of Capital Adequacy commercial banks in Ethiopia. To this end, this study tried to provide real information about the determinant factors affecting CAR of commercial banks.

\section{Objective of the Study \\ General Objective}

The general objective of this study is to examine the effect of bank specific and macroeconomic determinants on capital adequacy Ethiopian Commercial banks.

Specific objective

1. To analyzes the effect of specific banks on capital adequacy of commercial bank of Ethiopia

2. To examine the effects macro-economic factors on capital adequacy of commercial banks in Ethiopia

\section{Hypothesis of the Study}

H 1: Bank Size has statistically significant and negative impact on CAR.

H 2: Deposit to Asset Ratio has statistically significant and negative impact on CAR.

$\mathrm{H}$ 3: Loan to asset ratio has statistically significant and negative impact on CAR.

H 4: Loan to deposit ratio has statistically significant and positive impact on CAR.

H 5: Loan loss provision has statistically significant and negative impact CAR

H 6: Return on asset has statistically significant and positive impact on CAR.

H 7: Return on equity has statistically significant and positive impact CAR.

$\mathrm{H}$ 8: Real gross domestic product growth has statistically significant and rate negative impact CAR.

H 9: Inflation Rate has statistically significant and negative impact CAR.

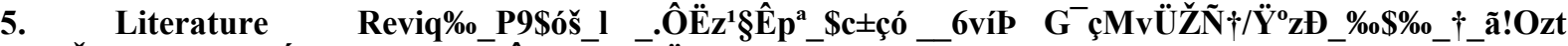

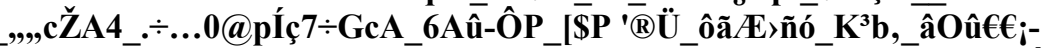

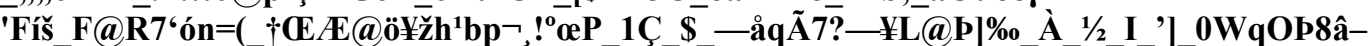
(B) $\overline{\mathbf{L}} \dot{\mathbf{0}}>" \ddot{\mathbf{A}}$

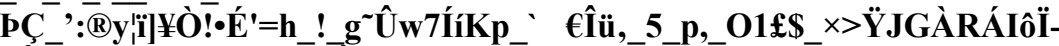

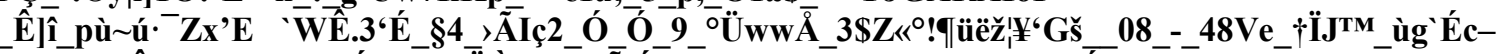

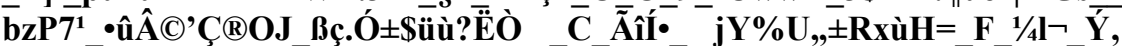

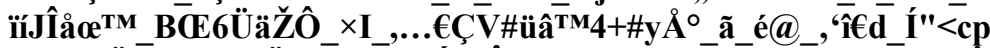

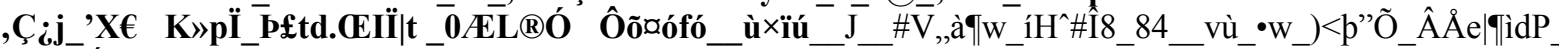

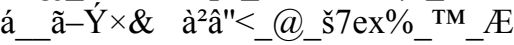

